\title{
Comparative Study between Two Doses of Intravenous Ondansetron on Maternal Haemodynamics during Elective Caesarean Delivery under Spinal Anaesthesia
}

\author{
SOHAIR A. MOHAMED, M.D.; RANDA A. SHOUKRY, M.D.; MUSTAFA M. HUSSIEN, M.D. and \\ AHMED S. KHALIFA SAYED, M.Sc.
}

The Department of Anaesthesiology, Intensive Care and Pain Management, Faculty of Medicine, Ain Shams University

\begin{abstract}
Background: Hypotension is one of the most common intra-operative complications associated with spinal anaesthesia. Its incidence in caesarean section has been estimated to be as high as $50-60 \%$. Despite fluid preloading, lateral uterine displacement and the use of vasopressor agents. It occurs due to sympathetic block which leads to autonomic nervous system disturbances and a decrease in systemic vascular resistance. This can occur because the level of block must be at least at $\mathrm{T} 4$ to ensure adequate analgesia severe hypotension following spinal anaesthesia in caesarean section is a dangerous complication. If it is unnoticed or inadequately treated, it can lead to serious maternal or fetal compromise.
\end{abstract}

Aim of Study: To evaluate the effect of two doses of prophylactic ondansetron on spinal anesthesia-induced hypotension and bradycardia among patients undergoing elective cesarean deliveries.

Patients and Methods: This study was carried out in Ain Shams Hospital Obstetric Theatres from March 2020 to September 2020. Written informed consent was obtained from every parturient included in the study. Ethical approval for this study was provided by the Ethics Committee of Faculty of Medicine, Ain Shams University. FAMSU MS 155/2020 (FWA 000017585) 23/2/2020.

Results: In our study, there is statistically significant difference between the studied groups regarding dose of vasopressor use. About $53.3 \%$ and $46.7 \%$ of those within ondansteron $4 \mathrm{mg}$ group received 10 and $12.5 \mathrm{mg}$ respectively. About $51.1 \%$ and $48.9 \%$ of those within ondansteron $8 \mathrm{mg}$ group received 12 and $15 \mathrm{mg}$ respectively. In terms of side effects, no patient within either group developed shivering, vomiting or bradycardia. Regarding nausea, there is statistically non-significant difference between the studied groups regarding occurrence of nausea.

Conclusion: Prophylactic bolus of intravenous onandsetron $8 \mathrm{mg}$ and to a lesser extent $4 \mathrm{mg}$ could decrease the fall in the MBP of parturients following spinal anesthesia as well as ephedrine needed dose that could decrease neonatal acidosis associated with ephedrine use.

Correspondence to: Dr. Ahmed S. Khalifa Sayed, E-Mail: anes.ahmedkhalifaammar@yahoo.com
Key Words: Bezold-Jarisch reflex-American Society of Anesthesiologists.

\section{Introduction}

HYPOTENSION is one of the most common intra-operative complications associated with spinal anaesthesia. Its incidence in caesarean section has been estimated to be as high as 50-60\% [1]. Despite fluid preloading, lateral uterine displacement and the use of vasopressor agents [1]. It occurs due to sympathetic block which leads to autonomic nervous system disturbances and a decrease in systemic vascular resistance $[3,4]$. This can occur because the level of block must be at least at T4 to ensure adequate analgesia severe hypotension following spinal anaesthesia in caesarean section is a dangerous complication. If it is unnoticed or inadequately treated, it can lead to serious maternal or fetal compromise [4,5].

Several measures were adopted to prevent or at least reduce the incidence of hypotension induced by spinal anaesthesia. In spite of using all the prophylactic measures, none of them can totally avoid maternal hypotension post-spinal anaesthesia. Therefore, there should be an interventional study to prevent or at least reduce the incidence of hypotension following spinal anesthesia in caesarean section [9].

Ondansetron is a highly specific and selective serotonin 5-HT3 receptor antagonist with low affinity for dopamine receptors. Several studies have shown that it can prevent hypotension after spinal anaesthesia in pregnant and non-pregnant women $[10,11]$. A recent meta-analysis concluded that ondansetron may reduce the incidence of hypotension induced by spinal anesthesia $[\mathbf{1 4 , 1 6}$. 
The mechanism of action is believed to be inhibition of the Bezold-Jarisch Reflex (BJR).

In this study two doses of Ondansetron will be compared to prevent or at least reduce post-spinal hypotension in caesarean section $[\mathbf{1 2 , 1 3 ]}$

\section{Patients and Methods}

\section{Technical design:}

Site of study: This study was carried out in Ain Shams Hospital Obstetric Theatres. Written informed consent was obtained from every parturient included in the study. Ethical approval for this study was provided by the Ethics Committee of Faculty of Medicine, Ain Shams University. FAMSU MS 155/2020 (FWA 000017585) 23/2/2020.

Sample size: A comprehensive sample was taken including pregnant patients during period of six months. A group sample size of at least 45 cases per group in two groups achieved $80 \%$ power to detect a moderate to large effect size of 96 and a significance level of 0.05 using two sided two samples independent $t$-test. Therefore, the sample was 90 cases. Patients were randomly assigned into 2 groups; each group was 45 patients.

Inclusion criteria: Full-term. Singleton. Age from 18 to 35 years old. Physical status; American Society of Anesthesiologists (ASA) I and II. Type of operation; elective cesarean section under spinal anesthesia.

Exclusion criteria: Patient refusal. Patients with contraindications to spinal anesthesia (e.g. infection, vertebral column deformity, or coagulopathy). Patients with hypersensitivity to the used drugs. Pre-operative use of ondansetron. Patients with severe cardiac, pulmonary, renal, hepatic, neuromuscular disorders and diabetes mellitus. Patients who take antidepressants in the form of selective serotonin reuptake inhibitors or on migraine therapy. Patients with morbid obesity, pregnancy-induced hypertension. Parturients with highrisk pregnancy.

\section{Operational design:}

Type of study: Randomized, prospective, double blinded clinical trial.

\section{Methods:}

Parturients had to be fasting for $6 \mathrm{hr}$. before the operation. In the preparation room, consent was taken, history was taken from all patients with documentation of the age, American Society of Anesthesiologists' score and gestational age. Then, pre-operative preparations were done to all patients in the form of recording the laboratory investigations as complete blood picture, coagulation profile, liver, and renal functions and after that an intravenous access will be obtained. Then, the patient was transferred to the operating room and baseline vital signs were recorded 30 minutes before conduction of anaesthesia including non-invasive measurement of systolic, mean, diastolic arterial pressures, heart rate, ECG, oxygen saturation and urine output. A peripheral $18-\mathrm{G}$ intravenous (i.v.) cannula was inserted into the dorsum of the nondominant hand and a preload of $5 \mathrm{ml} / \mathrm{kg}$ of warm normal saline $0.9 \%$ was administered. An infusion of $5 \mathrm{ml} / \mathrm{kg}$ of saline solution was administrated approximately 15-30 minutes before anaesthesia. Patients were randomly assigned into 1 of 2 groups, using computer generated sequence and opaque envelopes, according to the prophylactic intravenous drug dose used:

- Group 1 (45 patients): Patients received 4mg ondansetron IV in $5 \mathrm{ml}$. normal saline 5 minutes before spinal anesthesia.

- Group 2 (45 patients): Patients received 8mg ondansetron IV in $5 \mathrm{ml}$. normal saline 5 minutes before spinal anesthesia.

The patient was placed in the sitting position, sterilization of the back and local anaesthetic infiltration was done. After that, spinal anaesthesia was performed at the level L3-L4 or L2-L3 with a 25G Whitacre needle using a hyperbaric bupivacaine solution $5 \mathrm{mg} / \mathrm{ml}$. In a dose of $0.06 \mathrm{mg} / \mathrm{cm}$ patient's height with 15ug fentanyl solution [14].

The patient was placed in a supine position immediately after regional blockade with a left lateral tilt. The sensory and motor block was assessed bilaterally by cold discrimination using a frozen sachet of normal saline or ice cube and by modified bromage scale (0: No motor block, 1 : Inability to raise extended legs, 2 : Inability to flex knees, 3: Inability to flex ankle joints) respectively to ensure adequate anaesthetic block.

Sensory block was examined by loss of sensation to pin prick at midclavicular line every $2 \mathrm{~min}$ until fixation of the sensory level in two consecutive times. The surgeon could start surgery when the sensory block level was established at T6. Time to reach the highest sensory level from the injection time of bupivacaine into the subarachnoid space was recorded.

All hemodynamic parameters (as blood pressure using non-invasive measurement, heart rate and oxygen saturation) were immediately recorded after resuming the supine position then every 5 
minutes in the first 30 minutes and then every 10 minutes until skin closure. Oxygenation was facilitated by using nasal cannula at flow of $3-4 \mathrm{~L} / \mathrm{min}$. Other complications of hypotension as dizziness, nausea, vomiting, post anaesthetic shivering as well as side effects of the used drugs were monitored and recorded. In case of failed spinal anesthesia, patient was informed, and general anesthesia was delivered. MBP, HR, and oxygen saturation $\left(\mathrm{SpO}_{2}\right)$ were recorded.

Side effects of ondanestron were headache, fatigue, constipation, diarrhea, dizziness, rash, hiccup, and flushing. Hypotension is defined as a decrease of mean arterial pressure $20 \%$ below the baseline. In case of hypotension, $10 \mathrm{mg}$ of ephedrine with $100 \mathrm{ml}$. Normal saline was administrated intravenously and was repeated until restoration of baseline values $[8]$.

\section{Outcomes:}

The primary investigated outcome was the incidence of post-spinal hypotension in caesarean section. Secondary outcomes included nausea, vomiting, bradycardia, total dose of vasopressors used and shivering.

Vomiting was treated by $10 \mathrm{mg}$ i.v. bolus dose of metclopromide. Bradycardia was defined as HR below 60 beat $/ \mathrm{min}$. and it was treated by a $0.5 \mathrm{mg}$ i.v. bolus dose of atropine, followed by incremental doses of $0.1 \mathrm{mg}$ as required.

\section{Statistical analysis:}

Data analysis was performed using the software SPSS (Statistical Package for the Social Sciences) version 20. Quantitative variables were described using their means and standard deviations. Categorical variables were described using their absolute frequencies and to compare the proportion of categorical data, chi-square test and fisher exact tests were used when appropriate. Kolmogorov-Smirnov (distribution-type) and Levene (homogeneity of variances) tests were used to verify assumptions for use in parametric tests.

To compare quantitative parameters among two groups, independent sample $t$-test (for normally distributed data) and Mann Whitney test (for not normally distributed data) were used. To compare change over time in means in each group, repeated measure ANOVA test (for normally distributed data) was used.

The level of statistical significance was set at $5 \%(p<0.05)$. Highly significant difference was present if $p \leq 0.001$.

\section{Results}

Table (1): Distribution of the studied groups according to baseline characteristics, and ASA.

\begin{tabular}{|c|c|c|c|c|}
\hline \multirow{2}{*}{ Parameters } & \multicolumn{2}{|c|}{ Groups } & \multicolumn{2}{|c|}{ Test } \\
\hline & $\begin{array}{l}\text { Ondansteron } 4 \mathrm{mg} \\
\text { group }(\mathrm{n}=45)\end{array}$ & $\begin{array}{l}\text { Ondansteron } 4 \mathrm{mg} \\
\text { group }(\mathrm{n}=45)\end{array}$ & $t / \chi^{2}$ & $p$ \\
\hline $\begin{array}{l}\text { Age (year): } \\
\text { Mean } \pm \mathrm{SD} \\
\text { Range }\end{array}$ & $\begin{array}{l}31.84 \pm 5.608 \\
25-49\end{array}$ & $\begin{array}{l}30.29 \pm 5.723 \\
18-40\end{array}$ & 1.302 & 0.169 \\
\hline $\begin{array}{l}\text { Weight }(\mathrm{kg}) \text { : } \\
\text { Mean } \pm \mathrm{SD} \\
\text { Range }\end{array}$ & $\begin{array}{l}72.71 \pm 9.82 \\
60-97\end{array}$ & $\begin{array}{l}76.18 \pm 6.82 \\
55-90\end{array}$ & -1.945 & 0.055 \\
\hline $\begin{array}{l}\text { Height }(\mathrm{cm}): \\
\text { Mean } \pm \mathrm{SD} \\
\text { Range }\end{array}$ & $\begin{array}{l}167.91 \pm 8.439 \\
156-180\end{array}$ & $\begin{array}{l}170.6 \pm 4.277 \\
159-180\end{array}$ & -1.907 & 0.061 \\
\hline $\begin{array}{l}B M I\left(\mathrm{~kg} / \mathrm{m}^{2}\right): \\
\text { Mean } \pm \mathrm{SD} \\
\text { Range }\end{array}$ & $\begin{array}{l}25.743 \pm 2.507 \\
20.047-33.594\end{array}$ & $\begin{array}{l}26.163 \pm 2.035 \\
19.031-29.388\end{array}$ & -0.872 & 0.385 \\
\hline $\begin{array}{l}\text { Gestational ag } \\
\text { (week): } \\
\quad \text { Mean } \pm \text { SD } \\
\text { Range }\end{array}$ & $\begin{array}{l}38.56 \pm 0.659 \\
38-40\end{array}$ & $\begin{array}{l}38.38 \pm 0.912 \\
37-40\end{array}$ & 1.06 & 0.292 \\
\hline $\begin{array}{l}\text { ASA: } \\
\quad \text { I } \\
\text { II }\end{array}$ & $\begin{array}{l}44(97.8) \\
1 \quad(2.2)\end{array}$ & $\begin{array}{lr}39 & (86.7) \\
6 & (13.3)\end{array}$ & Fisher & 0.11 \\
\hline
\end{tabular}

$t_{2}:$ Independent sample $t$-test.

$\chi^{2}$ : Chi square test.

$p>0.05$ is statistically non-significant.

Table (2): Comparison between the studied groups regarding heart rate findings over time.

\begin{tabular}{lllll}
\hline & $\begin{array}{c}\text { Ondansteron } \\
4 \mathrm{mg}\end{array}$ & $\begin{array}{c}\text { Ondansteron } \\
8 \mathrm{mg}\end{array}$ & & \\
Heart rate & $\begin{array}{c}\text { group (n=45) } \\
\text { Mean } \pm \mathrm{SD}\end{array}$ & $\begin{array}{c}\text { group (n=45) } \\
\text { Mean } \pm \mathrm{SD}\end{array}$ & & \multicolumn{1}{c}{$t$} \\
& & & \\
\hline - 30min. before & $87.13 \pm 3.527$ & $85.64 \pm 4.558$ & 1.733 & 0.087 \\
induction & & & & \\
- On induction & $90.31 \pm 4.522$ & $87.47 \pm 3.917$ & 3.189 & $0.002^{*}$ \\
- At 5 minutes & $88.93 \pm 3.928$ & $83.2 \pm 5.268$ & 5.853 & $<0.001^{* *}$ \\
- At 10 minutes & $88.27 \pm 3.085$ & $80.96 \pm 4.311$ & 6.23 & $<0.001^{* *}$ \\
- At 15 minutes & $87.36 \pm 2.414$ & $82.84 \pm 4.194$ & -3.451 & $0.002^{*}$ \\
- At 20 minutes & $87.33 \pm 2.403$ & $82.93 \pm 3.033$ & 6.21 & $<0.001^{* *}$ \\
- At 25 minutes & $84.29 \pm 3.259$ & $78.29 \pm 9.605$ & 3.968 & $<0.001^{* *}$ \\
- At 30 minutes & $84.96 \pm 4.467$ & $80.56 \pm 9.715$ & 2.76 & $0.008^{*}$ \\
- At 40 minutes & $86.16 \pm 3.778$ & $86.67 \pm 10.002$ & -0.321 & 0.75 \\
- At 50 minutes & $87.78 \pm 3.45$ & $82.27 \pm 10.616$ & 3.312 & $0.002^{*}$ \\
- At 60 minutes & $87.73 \pm 2.606$ & $86.78 \pm 6.557$ & 0.908 & 0.367 \\
- P(F) & $<0.001 * *$ & $<0.001 * *$ & & \\
\hline
\end{tabular}

$t \quad:$ Independent sample $t$-test

$\mathrm{F}$ : Repeated measure ANOVA test.

* : $p<0.05$ is statistically significant.

$* *: p \leq 0.001$ is statistically highly significant.

Table (3): Comparison between the studied groups regarding heart rate findings over time.

\begin{tabular}{lcccc}
\hline $\begin{array}{l}\text { Maximum } \\
\text { change } \\
\text { in heart rate }\end{array}$ & $\begin{array}{c}\text { Ondansteron } \\
4 \mathrm{mg} \\
\text { group }(\mathrm{n}=45) \\
\text { Mean } \pm \mathrm{SD}\end{array}$ & $\begin{array}{c}\text { Ondansteron } \\
8 \mathrm{mg} \\
\text { group }(\mathrm{n}=45) \\
\text { Mean } \pm \mathrm{SD}\end{array}$ & $\mathrm{Z}$ & $p$ \\
\hline Median (range) & $3(-6,11)$ & $11(1,21)$ & -2.74 & $0.006^{*}$ \\
\hline$*: p<0.05$ is statistically highly significant. Z: Mann Whitney test.
\end{tabular}


Table (4): Comparison between the studied groups regarding mean arterial blood pressure findings over time.

\begin{tabular}{|c|c|c|c|c|}
\hline MAP & $\begin{array}{c}\text { Ondansteron } \\
4 \mathrm{mg} \\
\text { group }(\mathrm{n}=45) \\
\text { Mean } \pm \text { SD }\end{array}$ & $\begin{array}{c}\text { Ondansteron } \\
8 \mathrm{mg} \\
\text { group }(\mathrm{n}=45) \\
\text { Mean } \pm \mathrm{SD}\end{array}$ & $t$ & $p$ \\
\hline $\begin{array}{l}\text { - } 30 \mathrm{~min} \text {. before } \\
\text { induction }\end{array}$ & $81.02 \pm 8.706$ & $79.56 \pm 8.92$ & 0.789 & 0.432 \\
\hline - On induction & $79.69 \pm 5.896$ & $81.49 \pm 8.468$ & -1.17 & 0.245 \\
\hline - At 5 minutes & $76.47 \pm 5.845$ & $77.6 \pm 8.405$ & -0.743 & 0.46 \\
\hline - At 10 minutes & $75.56 \pm 4.874$ & $76.27 \pm 8.3$ & 6.23 & 0.622 \\
\hline - At 15 minutes & $71.82 \pm 5.674$ & $75.04 \pm 6.303$ & -0.496 & $0.002 *$ \\
\hline - At 20 minutes & $69.04 \pm 5.604$ & $71.27 \pm 6.583$ & -2.549 & $0.013^{*}$ \\
\hline - At 25 minutes & $68.04 \pm 4.327$ & $68.13 \pm 5.591$ & -1.742 & 0.088 \\
\hline - At 30 minutes & $69.27 \pm 5.565$ & $73.6 \pm 5.921$ & -3.577 & $0.001 * *$ \\
\hline - At 40 minutes & $73.8 \pm 4.251$ & $75.6 \pm 5.246$ & -1.788 & 0.077 \\
\hline - At 50 minutes & $74.09 \pm 5.67$ & $80.51 \pm 6.025$ & -5.169 & $<0.001 * *$ \\
\hline - At 60 minutes & $77.62 \pm 5.271$ & $83.04 \pm 6.954$ & -4.168 & $<0.001 * *$ \\
\hline$\cdot p$ & $<0.001 * *$ & $<0.001 * *$ & & \\
\hline
\end{tabular}

$t$ : Independent sample $t$-test.

$\mathrm{F}:$ Repeated measure ANOVA test.

* : $p<0.05$ is statistically significant.

: $p \leq 0.001$ is statistically highly significant.

Table (5): Comparison between the studied groups regarding maximum change in mean arterial blood pressure findings.

\begin{tabular}{lcccc}
\hline $\begin{array}{l}\text { Maximum } \\
\text { change in } \\
\text { blood pressure }\end{array}$ & $\begin{array}{c}\text { Ondansteron } \\
4 \mathrm{mg} \\
\text { group }(\mathrm{n}=45) \\
\text { Mean } \pm \mathrm{SD}\end{array}$ & $\begin{array}{c}\text { Ondansteron } \\
8 \mathrm{mg} \\
\text { group }(\mathrm{n}=45) \\
\text { Mean } \pm \mathrm{SD}\end{array}$ & $\mathrm{Z}$ & $p$ \\
\hline Median (range) & $10(0,19)$ & $13(1,24)$ & $-2.0340 .042^{*}$
\end{tabular}

$*: p<0.05$ is statistically highly significant.

Z: Mann Whitney test.

Table (6): Comparison between the studied groups regarding dose of vasopressor use.

\begin{tabular}{lllll}
\hline $\begin{array}{l}\text { Vasopressor } \\
\text { use }\end{array}$ & $\begin{array}{c}\text { Ondansteron } \\
4 \mathrm{mg} \\
\text { group }(\mathrm{n}=45) \\
\%\end{array}$ & $\begin{array}{c}\text { Ondansteron } \\
8 \mathrm{mg} \\
\operatorname{group}(\mathrm{n}=45) \\
\%\end{array}$ & $\chi^{2} / t$ & $p$ \\
\hline $10 \mathrm{mg}$ & $24(53.3)$ & $0(0)$ & 19.108 & $<0.001^{* *}$ \\
$12 \mathrm{mg}$ & $0(0)$ & $23(51.1)$ & & \\
$12.5 \mathrm{mg}$ & $21(46.7)$ & $0(0)$ & & \\
$15 \mathrm{mg}$ & $0(0)$ & $22(48.9)$ & & \\
Mean \pm SD & $11.222 \pm 1.264$ & $13.467 \pm 1.517$ & -7.626 & $<0.001^{* *}$ \\
Range & $10-12$ & $12-15$ & & \\
$\chi^{2}:$ Chi square for trend test. & & & \\
$* *: p \leq 0.001$ is statistically highly significant. & &
\end{tabular}

Table (7): Comparison between the studied groups regarding occurrence of shivering.

\begin{tabular}{lcccc}
\hline Shivering & $\begin{array}{c}\text { Ondansteron } \\
\text { 4mg group } \\
\mathrm{n}=45(\%)\end{array}$ & $\begin{array}{c}\text { Ondansteron } \\
8 \mathrm{mg} \text { group } \\
\mathrm{N}=45(\%)\end{array}$ & $\chi^{2}$ & $p$ \\
\hline No & $45(100)$ & $45(100)$ & 0 & $>0.999$ \\
$\chi^{2}:$ Chi square test. & & &
\end{tabular}

Table (8): Comparison between the studied groups regarding nausea, vomiting and bradycardia.

\begin{tabular}{llclc}
\hline Parameters & $\begin{array}{c}\text { Ondansteron } \\
\text { 4mg group } \\
\text { N=45 }(\%)\end{array}$ & $\begin{array}{c}\text { Ondansteron } \\
8 \mathrm{mg} \text { group } \\
\mathrm{N}=45(\%)\end{array}$ & $\chi^{2}$ & $p$ \\
\hline $\begin{array}{l}\text { Vomiting: } \\
\text { No }\end{array}$ & $45(100)$ & $45(100)$ & 0 & $>0.999$ \\
$\begin{array}{l}\text { Nausea: } \\
\text { No } \\
\text { Yes }\end{array}$ & $\begin{array}{l}4(91.1) \\
(8.9)\end{array}$ & $\begin{array}{l}35(77.8) \\
10(22.2)\end{array}$ & Fisher & 0.142 \\
$\begin{array}{l}\text { Bradycardia: } \\
\text { No }\end{array}$ & $45(100)$ & $45(100)$ & 0 & $>0.999$ \\
\hline$\chi^{2}:$ Chi square test. $\quad p>0.05$ is non-significant. & &
\end{tabular}

\section{Discussion}

Cesarean delivery is usually performed with spinal anesthesia to avoid the risks of general anesthesia. The advantages of spinal anesthesia such as rapidity, reliability, safety, ease of performance, and avoidance of the hazards of general anesthesia make it the goldstandard anesthetic technique for elective cesarean delivery [15]

Its use has a major limitation, which is development of hypotension and bradycardia, with a subsequent decrease in uteroplacental blood flow, which leads to fetal acidosis and increase in fetal morbidity and mortality [15]

Several techniques were tried to decrease the incidence and severity of maternal hypotension that usually follows spinal anesthesia include preloading with fluids, and left lateral tilt to prevent the gravid uterus from compression on the inferior vena cava, with a subsequent decrease in the venous return [6].

Spinal anesthesia induces sympathetic block that leads to vasodilatation, pooling of venous blood, decrease of venous return, and low ventricular volume state, which leads to activation of chemoreceptors and mechanoreceptors in the cardiac wall with abrupt withdrawal of sympathetic supply, and unopposed vagal tone to the heart, which leads to bradycardia and hypotension; this reflex is called the Bezold-Jarisch Reflex (BJR) and it is triggered by serotonin (5-HT3) released from thrombocytes under low ventricular volume conditions that stimulate cardiac chemoreceptors and increase the vagal tone. Serotonin (5-HT3) antagonists are suggested to be used in the prevention of hypotension and bradycardia caused by BJR in response to spinal anesthesia [16]

Onandsetron is a 5-HT3 antagonist that has been used to prevent nausea and vomiting caused by chemotherapy, radiotherapy, and surgery and 
there are clinical trials for its use in the prevention of BJR after spinal anesthesia in obstetric patients [17].

Serotonin (5-HT3) receptors are present in the spinal cord and it was found that the 5-HT3 level increased in the cerebrospinal fluid after spinal anesthesia with bupivacaine; thus, there was a query about the effects of the 5-HT3 antagonist onandsetron on the specifications of spinal anesthesia [18]

Ephedrine is a noncatecholamine sympathomimetic that has a and 0 adrenergic activity, and it is the classical vasopressor of choice for the treatment of postspinal hypotension in cesarean delivery, but it can induce maternal cardiovascular adverse effects such as supraventricular tachycardia, tachyphylaxis, and fetal acidosis [19].

The aim of this study was to evaluate the effect of two doses of prophylactic ondansetron on spinal anesthesia-induced hypotension and bradycardia among patients undergoing elective cesarean deliveries. Ninety pregnant patients were randomly divided into two groups:

- Group 1: 45 Patients received 4mg ondansetron in $5 \mathrm{ml}$ normal saline (IV).

- Group 2: 45 Patients received 8mg ondansetron in $5 \mathrm{ml}$ normal saline (IV).

In our study, there were statistically nonsignificant differences between the studied groups regarding age, weight, height, gestational age, BMI or ASA. Larger percentage within each group had ASA I (97.8\% and $86.7 \%$ within Ondansteron 4 and $8 \mathrm{mg}$ groups respectively).

Mohamed and Mansour [20] compared between two doses of ondansetron $(2 \mathrm{mg}, 4 \mathrm{mg}$ ) and ephedrine in prevention of maternal hypotension and bradycardia induced by spinal anesthesia. One hundred and twenty parturients were eligible for this study. The following groups were established: Group A received $2 \mathrm{mg}$ of ondansetron, group B received $4 \mathrm{mg}$ of onandsetron, group $\mathrm{C}$ received $10 \mathrm{mg}$ of ephedrine, and group D received normal saline only. There was no significant difference between the four groups in parturients' demographic data and duration of surgery. There was a decrease in the HR values in the four groups in comparison with the baseline values that became significant in the ephedrine and control groups at 5,10, and $15 \mathrm{~min}$. HR values were the highest in the onandsetron $4 \mathrm{mg}$ group and the lowest in the ephedrine group, with a significant difference between the two groups of onandsetron ( 2 and $4 \mathrm{mg}$ ) and ephedrine, and the control groups at 5, 10, and 15 minutes.

In terms of the changes in the heart rate, there is statistically non-significant difference between the studied groups regarding heart rate 30 minutes before induction, 40 or 60 minutes after induction. On the other hand, there is statistically significant difference between them regarding heart rate at induction, at $5,10,15,20,25,30$, and 50 minutes after induction. Both groups showed significant change in heart rate over time. Also, there is statistically significant difference between both groups regarding maximum change in heart rate. Owczuk et al., [21] studied 72 parturients scheduled for cesarean delivery with spinal anesthesia by $4 \mathrm{ml}$ of $0.5 \%$ bupivacaine and the parturients were treated with $8 \mathrm{mg}$ of onandsetron as a prophylaxis for postspinal hypotension and they found that $8 \mathrm{mg}$ onandsetron had no influence on the decrease in HR after spinal anesthesia, which could be explained by the high dose of intrathecal bupivacaine (20mg) used in the study.

In terms of the changes in the mean arterial blood pressure, there is statistically non-significant difference between the studied groups regarding mean arterial blood pressure 30 minutes before induction and 5, 10, 25 and 40 minutes after induction. On the other hand, there is statistically significant difference between them regarding mean arterial blood pressure at induction, at 15, 20,30, 50 and 60 minutes after induction. Both groups showed significant change in mean arterial blood pressure over time. Also, there is statistically significant difference between both groups regarding maximum change in blood pressure. It affect MBP and systolic but not diastolic Owczuk et al., [21] found that $8 \mathrm{mg}$ onandsetron could attenuate the decrease of systolic and MBP only, but it had no influence on the decrease in diastolic blood pressure after spinal anesthesia.

Sahoo et al., [10], in their study on 52 parturients scheduled for elective cesarean delivery under spinal anesthesia and parturients who were treated with $4 \mathrm{mg}$ onandsetron, observed a significant reduction in MAP at 5 minutes, 6 minutes in the control group and significant reduction in MAP between 14 and 35 minutes only in the control group compared to pre-operative values. The incidence of decreases in SBP and MAP were reduced with the use of intravenous ondansetron $4 \mathrm{mg}$ given 5 minutes before SA in parturients undergoing elective caesarean section. 
In our study, there is statistically significant difference between the studied groups regarding dose of vasopressor use. About $53 \%$ and $47 \%$ of those within ondansteron $4 \mathrm{mg}$ group received 10 and $12.5 \mathrm{mg}$ respectively. About $51 \%$ and $49 \%$ of those within ondansteron $8 \mathrm{mg}$ group received 12 and $15 \mathrm{mg}$ respectively.

Sahoo et al., [10] found that onandsetron decreased the requirement of vasopressor use.

Rashad and Farmawy [22] concluded that in parturient females undergoing elective cesarean section, intravenous $4 \mathrm{mg}$ ondansetron before subarachnoid block significantly decreased the doses of vasopressor used.

Ortiz-Gómez et al., [11], in their post-operative randomized placebo-controlled trial on 128 pregnant women scheduled for elective cesarean delivery with spinal anesthesia, found that prophylactic $2,4,8 \mathrm{mg}$ of onandsetron played no role in reducing vasopressor consumption; this difference may be related to the dose of intrathecal bupivacaine that was individualized in each parturient to be $9.7 \pm$ $0.4 \mathrm{mg}$ in the placebo group and $9.6 \pm 0.3 \mathrm{mg}$ in the onandsetron group.

Wang et al., [12] studied 66 parturients scheduled for elective cesarean section under spinal anesthesia and found that prophylactic administration of $4 \mathrm{mg}$ onandsetron $5 \mathrm{~min}$. before spinal anesthesia with crystalloid preloading decreased vasopressor requirements.

Khalifa [23] compared a traditional vasopressor 'ephedrine' with 'ondansetron' in preventing hypotension of spinal anesthesia during cesarean section. They concluded that prophylactic i.v. use of $4 \mathrm{mg}$ ondansetron, and $10 \mathrm{mg}$ ephedrine reduces the need for rescue vasopressor. Gao et al., [24], in a metaanalysis study conducted on 863 patients, found that prophylactic onandestron reduced vasopressor consumption in obstetric patients.

In terms of shivering, no patient within either group developed shivering. Shakya et al., [25] suggested that the prophylactic administration of low-dose ketamine $(0.25 \mathrm{mg} / \mathrm{kg})$ and ondansetron (4mg) produces significant antishivering effect in comparison with placebo in patients undergoing spinal anesthesia.

Gao et al., [24] found that prophylactic onandestron reduced shivering. Mohamed and Mansour [20] found that incidence of shivering was higher in the control group (50\%) in comparison with the other groups; where it was $20 \%$ in the onandsetron
$2 \mathrm{mg}$ group, and $13.3 \%$ in the onandsetron $4 \mathrm{mg}$ group.

In our study, no patient within either group developed vomiting or bradycardia. Marashi et al., [26] compared prophylactic i.v. onandsetron 6 and $12 \mathrm{mg}$ and placebo in the attenuation of bradycardia, and they concluded that pretreatment with either 6 or $12 \mathrm{mg}$ i.v. onandsetron could reduce hemodynamic changes following spinal anesthesia without significant differences between the two doses of onandsetron.

Trabelsi et al., [27] studied 80 parturients scheduled for cesarean delivery under spinal anesthesia with $10 \mathrm{mg}$ bupivacaine plus 2.5 suefentanil after preloading with $10 \mathrm{ml} / \mathrm{kg}$ saline; half of them received $4 \mathrm{mg}$ onandsetron $5 \mathrm{~min}$ before spinal anesthesia and it was found that onandsetron could protect the parturients against bradycardia. They suggested that onandsetron has a dual action: On the heart, improving contractility. Gao et al., [24] found that prophylactic onandestron reduced vomiting. Mohamed and Mansour [20] found thatnone of the parturients developed bradycardia in the onandsetron group.

Regarding nausea,there is statistically nonsignificant difference between the studied groups regarding occurrence of nausea (non-significantly higher among Ondansteron $8 \mathrm{mg}$ group $22.2 \%$ versus $8.9 \%$ in Ondansteron $4 \mathrm{mg}$ group).

Wang et al., [12] concluded that $4 \mathrm{mg}$ of ondansetron preloading was the optimal dose to prevent nausea, and other adverse effects during cesarean delivery.

Gao et al., [24] found that prophylactic onandestron reduced nausea.

Khalifa [23] concluded that prophylactic i.v. use of $4 \mathrm{mg}$ ondansetron, and $10 \mathrm{mg}$ ephedrine reduces the incidence of nausea. Mohamed and Mansour [20] found that none of the parturients complained of nausea in the onandsetron 2 and $4 \mathrm{mg}$ groups.

Pazoki et al., [28] evaluated the efficiency of two doses (8mg and $4 \mathrm{mg}$ ) of ondansetron in preventing PONV in 195 patients referred for cesarean section $(\mathrm{C} / \mathrm{S})$ under spinal anesthesia, and then the subjects were assigned to three equally sized groups using block randomization. Participants in the first, second, and control groups received $8 \mathrm{mg}, 4 \mathrm{mg}$ of ondansetron, and normal saline, respectively, 5 minutes before surgery. A final volume of $5 \mathrm{cc}$ was prepared by adding normal saline. The PONV incidence was significantly higher in the placebo 
group than in the other two groups at 24 hours. The hemodynamic variables were same in three groups. They concluded that the PONV was lower in $8 \mathrm{mg}$ ondansetron than $4 \mathrm{mg}$ ondansetron. The decreasing effect of MBP and MHR was same in all groups.

Our study estimated the dose of ephedrine from previous researches that studied the effect of different doses of ephedrine on the prevention of hypotension that developed after spinal anesthesia. Loughrey et al., [29] compared two doses of prophylactic ephedrine (6 and 12mg) and placebo in 68 parturients scheduled for cesarean delivery under spinal anesthesia and found that the higher dose $(12 \mathrm{mg})$ of ephedrine was associated with less incidence of hypotension.

Magalhães et al., [30] compared prophylactic i.v. $10 \mathrm{mg}$ ephedrine and $80 \mu \mathrm{g}$ phenylepherine and found that $10 \mathrm{mg}$ of ephedrine would be efficient prophylaxis for postspinal hypotension in parturients with slight neonatal acidosis, but without serious clinical effects on the neonatal condition as shown by the Apgar score, and suggested that the lower $\mathrm{pH}$ values in the ephedrine group were linked to the increased fetal metabolism by the 3 adrenergic activity of ephedrine.

Gunda et al., [31] studied 100 parturients scheduled for cesarean section under spinal anesthesia and found that a prophylactic i.v. bolus dose of $5 \mathrm{mg}$ ephedrine was efficient in the prevention of postspinal hypotension and the neonatal outcome was satisfactory as shown by the Apgar score at 1 and $5 \mathrm{~min}$.

In terms of the effect of onandsetron on the characteristics of spinal anesthesia, this study found that i.v.onandsetron had no effect on the onset, duration, and the level of sensory, and motor block of spinal anesthesia, although it was assumed that onandsetron, which is a 5-HT3 antagonist, would affect the onset, duration, and intensity of spinal anesthesia as the serotonin (5-HT3) level in cerebrospinal fluid increased after spinal anesthesia. This is in agreement with the study of Samra et al., [32], who evaluated the effects of systemic $4 \mathrm{mg}$ onandsetron on the characteristics of spinal anesthesia in urinary bladder tumors, and concluded that it had no effects on the intensity or the duration of motor or sensory block; this difference could be attributed to the action of onandsetron on other receptors such as adrenergic, histaminic, dopaminergic, and opioid receptors.

This study had a major limitation: Cardiac output and systemic vascular resistance should have been measured to evaluate the effects of onandsetron on cardiac contractility, but these measurements require invasive hemodynamic monitoring such as a Swan-Ganz catheter or tansesophageal echo, which was difficult in conscious female patients.

\section{Conclusion:}

Prophylactic bolus of intravenous onandsetron $8 \mathrm{mg}$ and to a lesser extent $4 \mathrm{mg}$ could decrease the fall in the MBP of parturients following spinal anesthesia as well as ephedrine needed dose that could decrease neonatal acidosis associated with ephedrine use.

\section{References}

1- NORRIS M.C.: Spinal Anesthesia for caesarean section. Handbook of obstretic anesthesia, 309-12, 2000.

2- RUSSEL I.F.: Levels of Anaesthesia and intraoperative pain at caesarean section under regional block. Int. J. Obst. Anesth., 4 (2): 71-7, 1995.

3- CARPENTER R.L., CAPLAN R.A., BROWN D.L., STEPHENSON C. and WU R.: Incidence and risk factors for side effects of spinal anesthesia. Anesth., 76 (6): 906$16,1992$.

4- TARKKILA P.J. and KAUKINEN S.: Complications during spinal anesthesia: A prospective study. Reg. Anesth., 16 (2): 101-6, 1991.

5- HANSS R., BEIN B., WESELOH H., BAUER M., CAVUS E., STEINFATH M., et al.: Heart rate variability predicts severe hypotension after spinal anesthesia. Anesth., 104: 537-45, 2006

6- CYNA A.M., ANDREW M., EMMETT R.S., MIDDLETON P. and SIMMONS S.W.: Techniques for preventing hypotension during spinal anesthesia for caesarean section. Cockrane Database Syst. Rev., 4: CD002251, 2006.

7- MONK T.G., SAINI V., WELDON B.C. and SIGL J.C.] Anesthetic management and one-year mortality after non cardiac surgery. Anesth. Analg., 100: 4-10, 2005.

8- KINSELLA S.M., CARVALHO B., DYER R.A., FERNANDO R., McDONELL N., MERCIER F.J., et al.: International consensus statement on the management of hypotension with vasopressors during caesarean section under spinal anaesthesia. Anaesthesia, 73: 71-92, 2018.

9- MITRA J.K., ROY J., BHATTACHARYYA P., YUNUS M. and LYNGDOH N.M.: Changing trends in the management of hypotension following spinal anesthesia in cesarean section. J. Postgrad. Med., 59: 121-6, 2013.

10- SAHOO T., SENDASGUPTA C., GOSWAMI A. and HAZRA A.: Reduction in spinal- induced hypotension with ondansetron in parturient undergoing caesarean section: A double-blind randomized, placebo-controlled study. Int. J. Obstet. Anesth., 21: 24-8, 2012.

11- ORTIZ-GÓMEZ J.R., PALACIO-ABIZANDA F.J., MORILLAS-RAMIREZ F., FORNET-RUIZ I., LORENZOJIMENEZ A. and BERMEJO-ALBARES M.L.: The effect of intravenous ondansetron on maternal haemodynamics during elective caesarean delivery under spinal anesthesia: 
A double-blind, randomized, placebo-controlled trial. Int. J. Obstet. Anesth., 23: 138-43, 2014.

12- WANG M., ZHUO L., WANG Q., SHEN M.K., YU Y.Y., YU J.J., et al.: Efficacy of prophylactic intravenous ondansetron on the prevention of hypotension during Cesarean delivery: A dose-dependent study. Int. J. Clin. Exp. Med., 7: 5210-6, 2014.

13- WANG Q., ZHUO L., SHEN M.K., YU Y.Y., YU J.J. and WANG M.: Ondansetron preloading with crystalloid infusion reduces maternal hypotension during cesarean delivery. Am. J. Perinatol., 31: 913-22, 2014.

14- YUN S.H., SONG S.W. and PARK J.C.: Beneficial effects of the addition of intrathecal fentanyl to bupivacaine for spinal anesthesia in cesarean section. Anesth. Pain Med., 12: 233-9, 2017.

15- MEBAZAA M.S., OUERGHI S., BEN MEFTAH R., BEN CHEIKH M., MESTIRI T. and BEN AMMAR M.S.: Reduction of bupivacaine dose in spinal anaesthesia for caesarean section may improve maternal satisfaction by reducing incidence of low blood pressure episodes. Middle East J. Anaesthesiol., 20: 673-8, 2010.

16- NALLAM S.R. and DARA S.: Effect of intravenous ondansetron on reducing the incidence of hypotension and bradycardia events during shoulder arthroscopy in sitting position under interscalene brachial plexus block: A prospective randomized trial. Indian J. Anaesth., 59: 353-8, 2015.

17- CHRISTOFAKI M. and PAPAIOANNOU A.: Ondansetron: A review of pharmacokinetics and clinical experience in post-operative nausea and vomiting. Expert. Opin. Drug Metab. Toxicol., 10: 437-44, 2014.

18- FASSOULAKI A., MELEMENI A., ZOTOU M. and SARANTOPOULOS C.: Systemic ondansetron antagonizes the sensory block produced by intrathecallidocaine. Anesth. Analg., 100: 1817-21, 2005.

19- KANSAL A., MOHTA M., SETHI A.K., TYAGI A. and KUMAR P.: Randomized trial of intravenous infusion of ephedrine or mephentermine for management of hypotension during spinal anaesthesia for caesarean section. Anaesthesia, 60: 28-34, 2005.

20- MOHAMED A.Z.E. and MANSOUR H.S.: Assessment of the effect of two doses of prophylactic ondansetron on maternal hemodynamics, neonatal outcome and spinal blockade specifications, in parturients scheduled for cesarean delivery. Intensive Care, 5: 187-94, 2018.

21- OWCZUK R., WENSKI W., POLAK-KRZEMINSKA A., TWARDOWSKI P., ARSZU-OWICZ R., DYLCZYKSOMMER A., et al.: Ondansetron given intravenously attenuates arterial blood pressure drop due to spinal anesthesia: A double-blind, placebo-controlled study. Reg. Anesth. Pain Med., 33: 332-9, 2008.

22- RASHAD M.M. and FARMAWY M.S.: Effects of intra- venous ondansetron and granisetron on hemodynamic changes and motor and sensory blockade induced by spinal anesthesia in parturients undergoing cesarean section. Egypt J. Anaesth., 29: 369-74, 2013.

23- KHALIFA O.S.M.: A comparative study of prophylactic intravenous granisetron, ondansetron, and ephedrine in attenuating hypotension and its effect on motor and sensory block in elective cesarean section under spinal anesthesia. Ain-Shams Journal of Anesthesiology, 8: 166-72, 2015.

24- GAO L., ZHENG G., HAN J., WANG Y. and ZHENG J.: Effects of prophylactic ondansetron on spinal anesthesiainduced hypotension: A meta-analysis. Int. J. Obstet. Anesth., 24: 335-43, 2015.

25- SHAKYA S., CHATURVEDI A. and SAH B.P.: Prophylactic low dose ketamine and ondansetron for prevention of shivering during spinal anesthesia. Anaesthesiology Clinical Pharmacology, 26: 465-9, 2010.

26- MARASHI S.M., SOLTANI-OMI D.S., SOLTANI MOHAMMADI S., AGHAJANI Y. and MOVAFEGH A.: Comparing two different doses of intravenous ondansetronwith placebo on attenuation of spinal-induced hypotension and shivering. Anesth. Pain Med., 4: e 12-55, 2014.

27- TRABELSI W., ROMDHANI C., ELASKRI H., SAMMOUD W., BENSALAH M., LABBENE I., et al.: Effect of ondansetron on the occurrence of hypotension and on neonatal parameters during spinal anesthesia for elective caesarean section: A prospective, randomized, controlled, double-blind study. Anesthesiol. Res. Pract., 158061, 2015.

28- PAZOKI S., MODIR H., KAMALI A., ZAMANI A. and SHAHIDANI M.: Ondansetron 8mg and 4mg with normal saline against post-operative headache and nausea / vomiting after spinal anesthesia: A randomized double-blind trial. Med. Gas. Res., 8 (2): 48-53, 2018.

29- LOUGHREY J.P., WALSH F. and GARDINER J.: Prophylactic intravenous bolus ephedrine for elective Caesarean section under spinal anaesthesia. Eur. J. Anaesthesiol., 19: 63-8, 2002.

30- MAGALHÃES E., GOVÊIA C.S., De ARAÚJO LADEIRA L.C., NASCIMENTO B.G. and KLUTHCOUSKI S.M. Ephedrine versus phenylephrine: Prevention ofhypotension during spinal block for cesarean section and effects on thefetus. Rev. Bras. Anestesiol., 59: 11-20, 2009.

31- GUNDA C.P., MALINOWSKI J., TEGGINMATH A., SURYANARAYANA V.G. and CHANDRA S.B.: Vasopressor choice for hypotension in elective cesarean section: Ephedrine or phenylephrine? Arch. Med. Sci., 6: 257-63, 2010.

32- SAMRA T., BALA I., CHOPRA K. and PODDER S.: Effect of intravenous ondansetron on sensory and motor block after spinal anaesthesia with hyperbaric bupivacaine. Anaesth Intensive Care, 39: 65-8, 2011. 


\section{دراسة مقارنة بين جرعتين من الآوندانسيترون على الدوره الدموية

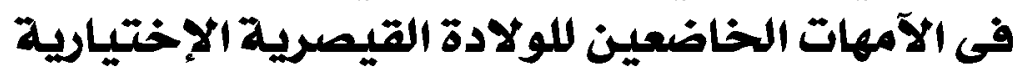 تحت تآثير التخدير التودة النصفى}

يعد إنخفاض ضغط الدم آحد آكثر المضاعفات آثناء العملية شيوعا المرتبطة بالتخدير النصفى.

كان الهدف من هذه الدراسة هو تقييم تآثير جرعتين من عقار آوندانسيترون الوقائى على إنخفاض ضغط الدم الناجم عن التخدير النصفى الني

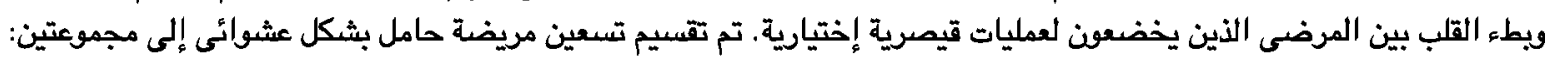
• المجموعة الآولى : 0 ع مريضاً تلقوا ع ملغ آوندانسيترون في ه مل من محلول ملح قديدياً.

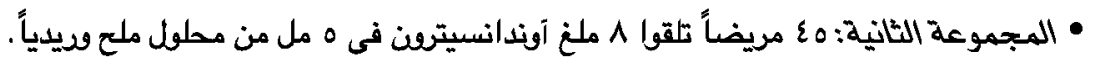

في دراستنا، توجد فروق ذات دالالة إحصائية بين المجموعات المدروبة فيما يتعلق بالعمر والنفن والطول وعمر الحمل ومؤثر كتلة الجسم

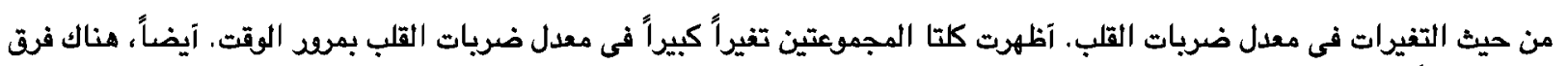

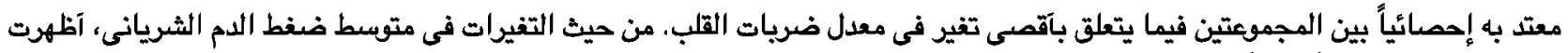

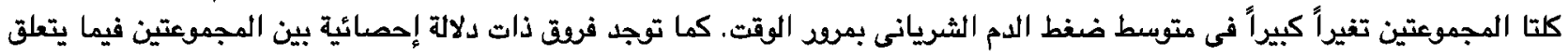
بآقصى تغير في ضغط الدم.

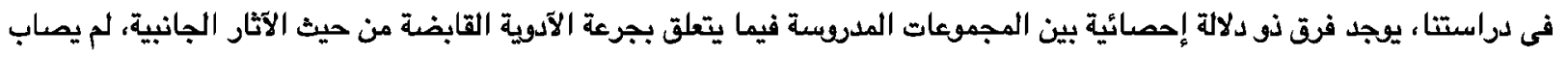

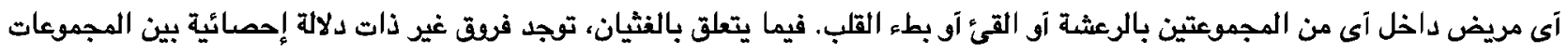

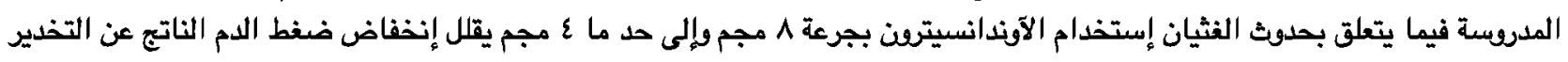

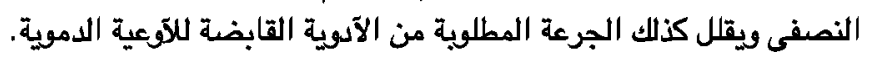

